にメジャーピークを，194，191ppmにも小さなピークを確認し， 3.0Tでより明瞭なピークの分離を認めた。

【結論】超偏極キセノンガス吸入により，1.5T，3.0Tに抢いて頭部溶 解相ダイナミックスペクトラムの収集に成功し，高磁場でより明瞭 なピーク分離を確認した。

【謝辞】本研究はNEDOによる助成を受けて行われた。

\section{4 薄型シャウカステンNEO30の開発}

オリオン電機(株) 林 博章, 本間龍夫，安井建造，三浦正和

【目的】従来のシャウカステンは，光拡散板(アクリル板)の背後に蛍 光灯などの光源を配置したものが多い．しかし，このようなシャウ カステンでは, 光搪散板上の輝度均一性向上のため光源を光搪散板 から離して配置することが必要である．従って，シャウカステンの 厚みが増し重量も重くなり卓上式や壁取付式あるいは，壁埋込式な ぞ固定配㯰での使用に限られていた，当社は，このたび熱陰極管を 光源とし導光板に隣接して線状光源を配置したエッジライト方式と することにより薄型化を図り，固定配置での使用のほか，院内何処 へでも手軽に持ち運びができ読影を可能にすると共にデザイン性に も優れた薄型シャウカステンNEO30を開発したので報告する.

【特長】1. 熱除極管の使用により，他社製冷陌極管のシャウカステン に比べ誘導電流が発生せず電気的に安全で医療現場にマッチしてい る．2．読影に必要な輝度が出ている．3．省エネタイプの熱陰極管 で長時間 $(9,000$ 時間：1 日 8 時間点灯で1,125日)ランプ交換が不要 である．4．厚さはわずか $34 \mathrm{~mm}$ とスリムな設計で持ち手付きは，何 処へでも手軽に運搬でき壁掛けにしても厚さが気にならず診察室に マッチするデザインである．5．照光面は，ガラス張りでアクリル板 のみに比べ傷が付かず読影間違いを起こすことなく長時間安心して 使用できる。

【結論】NEO30は，熱陰極管を光源としたエッジライト方式のシャウ カステンである。また，その駆動のための整流回路とそこで得られ る直流を高周波電流に変換するインバー夕部を有する電子安定器を 使用している，さらに，熱陰極管フィラメントのインピーダンス上 昇による発熱時異常状態からの回路保護機能も有している。これら の取りまとめにより，薄型化及び軽量化ができ，JISで規定される輝 度性能の実現が可能になった。

\section{Aquarius-NETによる遠隔画像配信システムの提案}

(株)エルクコーポレーション・医療システム営業本部 赤木信裕 【目的】遠隔画像連携の分野では, DICOM送受信時の，通信速度や デー夕量，セキュリティーなどが問題となる．今回，Aquarius-NET を利用した高速で安全な画像ネットワークの構築を提案する。

【方法】仮想プライベートネットワーク(VPN)でセキュリティー対策 した施設間で, インターネット接続し, 遠隔操作での処理スピード や操作性を確認し，メンテナンスを含めた実運用でのシステムの構 築方法を検討した.

【結果】1. Aquarius-NETは，大量の画像データを軽快にハンドリング できるネットワークシステムとして好評を得ている．2，バージョン 1.3に搭載されるMulti-node機能で，異なるモダリティーの画像が他 施設のAquarius-NETに保管されていても，複数サーバ画像を 1 つの クライアント上に統合して表示可能となった．3．仮想プライベート ネットワーク(VPN)を用いて接続することにより，セキュリティー を確保しながら，複数施設の画像の閲覧や合成が可能となった。 【考察】Aquarius-NETを利用した遠隔医療画像配信システムは, 診療 連携のツールとなる。
206 X線CT装置Aquilion ${ }^{\mathrm{TM}} 32$ 列システムの開発 東芝メディカルシステムズ(株)・CT事業部CT開発部 杉原直樹，浜田祐二

【目的】マルチスライスCTは, 短時間に広い範囲を高い分解能で撮影 することができる装置として，臨床現場に広く浸透している．また 最近では, 患者全身の高精細な検査だけでなく，心臟・循環器領域 の撮影も行われるようになってきた. 今回, さらに検査の精度と効 率をあげることを目的として，従来の約 2 倍の高速撮影を可能とし たX線CT装置を開発したので報告する。

【方法】より短時間に広い範囲を撮影できるようにフルスキャン 0.4 秒 で32列同時収集可能なシステムを開発した，検出器は $0.5 \mathrm{~mm} \times 64$ 列の 構成とし，スライス厚 $0.5 \mathrm{~mm}, 1 \mathrm{~mm}$ の2列同時収集が可能である. 検出器の多列化により収集デー夕量も増加するため，架台の回転部 から固定部へのデー夕伝送にはレーザー光を用いて 4Gbit/sec以上の デー夕伝送が可能な非接触デー夕伝送装置を開発して搭載した。本 装置は短時間に大量の画像デー夕を取得できる。このため, ワーク フローも向上を図った. 画像再構成装置を強化して再構成速度の高 速化を行い，かつスキャン系を処理するシステムと完全に分離する ことで，スキャン中も継続して画像再構成ができるようにした。さ らに大量のアキシャル画像を 1 つのボリュームデータとして簡便に 扱えるユーザインターフェースを装備した。

【結論】32列0.4秒スキャンの実現によって，臨床現場におけるほとん どの検査において 15 秒以下の短い撮影時間で高精細なボリューム デー夕を収集できるようになり，診断能と検査効率の向上が期待さ れる，今後，さらなる臨床価值の向上と普及に向けて，装置の機能 向上を目指す。

\section{CT検診アプリケーションの開発}

(株)日立メディコ・CTマーケティング統括部 高木 博 【目的】CT検診アプリケーションとしてCT肺がん検診関係の機能充 実を図っている，当社ではCT肺がん検診ではマルチスライスCTの 利用に伴う診断画像枚数の増加に対応した診断CAD機能を開発し販 売を行っている，今回，CT肺がん検診画像を利用した肺気腫計測機 能を追加した．更に皮下脂肪や内臓脂肪の正確な自動計測ができる 体脂肪測定アプりケーションを開発したので併せて紹介する。 【方法】生活習慣病の予防に役立つ肺気腫計測機能と体脂肪測定アプ リケーションの主な特長を示す１１．肺気腫計測はCT肺がん検診画 像を用いて肺野内の気腫性変化をしきい值処理により判定し面積の 算出や肺野面積に対する百分率を求める．2．肺気腫計測の客観的精 度向上や使い勝手を改善するために肺野領域や気腫性変化領域の自 動抽出を行っている．数值指標に加え肺気腫領域を黄色カラー表示 する. 3．体脂肪測定アプリケーションでは筋肉の内部領域を求め, 内部領域から筋肉, 骨領域を削除して内臟脂肪領域を算出する. 皮 下脂肪の場合は筋肉の外部領域から皮虔領域を削除し皮下脂肪領域 を算出する．4．内臓脂肪領域と皮下脂肪領域の平方 $\mathrm{cm}$ 表示に加之 色別にカラー表示する。内臟脂肪領域は赤色, 皮下脂肪領域は青色 のカラーリングを行っている.

【結果】CT検診アプリケーションは共同研究先の日立健康管理センタ で使用されている．肺気腫計測機能と体脂肪測定アプリケーション は日立健康管理センタで人間ドックに組み込まれ運用されている。 測定処理の自動化処理と医師による手動計測との比較で高い相関が 得られている。また測定の自動化により検査結果による検診者に 行っている生活習慣病に対する生活指導も人間ドック当日実施を可 能としている．体脂肪測定アプリケーションは検診者からも検査希 望が高く好評を得ている。 